Instructions/Template for Preparing Manuscript for Jendela Nursing Journal

\title{
Development of Management Information Systems with Integrated Clinical Pathway on the Quality of Nursing Services
}

\author{
Lia Dwi Jayanti ${ }^{1}$, Rr. Tutik Sri Hariyati ${ }^{1}$ \\ ${ }^{1}$ Nursing Department, Universitas Indonesia \\ Corresponding author: lia_dwijayanti@yahoo.com
}

\begin{abstract}
Background: Integrated Clinical Pathway (ICP) adalah rencana asuhan pasien terintegrasi dan terkoordinasi efektif antar multidisiplin dengan memanfaatkan sumber daya yang ada secara efisien dalam pelayanan kesehatan. Implementasi clinical pathway dapat menjadi sarana dalam terwujudnya peningkatan mutu pelayanan keperawatan. Akan tetapi, pengembangan dan penerapan ICP di Rumah Sakit tidaklah mudah karena pendokumentasian ICP dilakukan multidisiplin maka memerlukan pengetahuan yang mumpuni dan keterampilan klinis yang baik dalam menerapkan clinical pathway.

Purpose: Tujuan dari tinjauan literature review ini adalah untuk mengetahui pengembangan sistem informasi manajemen dengan Integrated Clincal Pathway terhadap mutu pelayanan keperawatan di Rumah Sakit.
\end{abstract}

Methods: Studi ini menggunakan perangkat penelitian PICO (Population, Intervention, Comparison, Outcome) dengan mengambil sumber dari EBSCO, ProQuest, Scopus, JKI dan artikel lain.

Results: Studi ini menunjukkan bahwa ICP yang terintegrasi dengan sistem informasi manajemen dapat menghemat waktu dan tenaga saat pemberian asuhan keperawatan professional.

Conclusion: Penerapan sosialisasi, pelatihan dan evaluasi clinical pathway yang optimal dapat meningkatkan mutu pelayanan keperawatan di rumah sakit.

Keywords:

Clinical Pathway; Nursing Services; Information System.

\section{LATAR BELAKANG}

Salah satu upaya oleh Badan Penyelenggaraan Jaminan Sosial (BPJS) Kesehatan sejak 1 Januari 2014 adalah memberikan pelayanan kesehatan sebagai upaya pelayanan kesehatan global (health coverage) dengan memberlakukan kepesertaan wajib bagi seluruh rakyat Indonesia yang diharapkan dapat memenuhi hak setiap warga negara dalam mendapatkan kesehatan. Badan Penyelenggara Jaminan Sosial Kesehatan akan 
membayar kepada fasilitas kesehatan tingkat pertama dengan sistem kapitasi dan untuk fasilitas kesehatan rujukan tingkat lanjutan dengan sistem paket Indonesia Case Based Groups (INA- CBG's). Penerapan tarif paket INA-CBGs ini menuntut manajemen rumah sakit untuk mampu mengefisiensi biaya dan mengoptimalkan pengelolaan keuangan rumah sakit, serta melakukan kendali mutu (Astuti, Dewi et al. 2017).

Clinical Pathway terintegrasi merupakan bagian penting dokumen yang melibatkan Profesional Pemberi Asuhan sebagai intradisiplin dan interdisiplin dengan kolaborasi interprofesional dalam pemberian asuhan pada pasien di Rumah Sakit (KARS, 2017). Implementasi clinical pathway dapat menjadi sarana dalam terwujudnya tujuan akreditasi rumah sakit yakni dalam meningkatkan mutu pelayanan rumah sakit, meningkatkan keselamatan pasien rumah sakit dan meningkatkan perlindungan bagi pasien, masyarakat serta sumber daya rumah sakit (Kemenkes, 2012).

Pada era globalisasi seperti sekarang ini rumah sakit dituntut untuk melaksanakan akreditasi baik secara nasional melalui Komite Akreditasi Rumah Sakit (KARS) maupun standar internasional melalui Joint Commission International (JCI) guna memperbaiki keselamatan dan kualitas dari pelayanan. Di Indonesia penerapan ICP terkait penerapan INA-DRG yang merupakan versi Departemen Kesehatan RI untuk Diagnostic Related Group (DRG's Casemix) yaitu sistem pembiayaan berdasarkan pendekatan sistem casemix, dimana diharapkan akan muncul efisiensi dan peningkatan mutu pelayanan kesehatan di rumah sakit (Adisasmito, 2008).

Maka, pada tahun 2010 telah dilakukan pertemuan konsolidasi kelompok kerja clinical pathway dalam pelaksanaan INA-DRG pada 15 rumah sakit vertikal Depkes sebagai Pilot Project di Indonesia (Depkes, 2010). Mutu pelayanan kesehatan adalah intervensi terintegrasi kepada klien secara aman dan sesuai standar profesi dengan memanfaatkan sumber daya yang terlatih sehingga kebutuhan pelangan dapat terpenuhi dan mencapai derajat kesehatan yang optimal. Mutu pelayanan keperawatan profesionalitas yang mengacu pada 5 dimensi kualitas pelayanan yaitu : reability, tangibles, assurance, responsiveness, dan empathy. Pengaruh faktor mutu pelayanan, antara lain: aspek kompetensi teknis, aspek pelayanan, efektifitas, efisiensi, hubungan antar manusia, keamanan, kenyamanan dan kesinambungan terhadap kepuasan pasien (Muninjaya, 2011).

Berdasarkan hasil sejumlah studi terkait manfaat Integrated Clinical Pathway, antara lain: melakukan pemantauan sesuai standar perawatan, peningkatan mutu pelayanan, dokumentasi yang baik, pelaksanan evidence-based best practice, meningkatkan kerjasama tim, mengurangi duplikasi, perbaikan manajemen resiko, dan pemberian perawatan berfokus pada pasien. Selain itu, ICP dapat mendukung infrastruktur kesehatan dengan menyediakan informasi yang relevan, akurat, dan tepat waktu yang diperlukan untuk memenuhi pemantauan strategis pelayanan pasien dan outcome.

\section{TUJUAN}

Tujuan dari tinjauan literature review ini adalah untuk mengetahui pengembangan sistem informasi manajemen dengan Integrated Clincal Pathway terhadap mutu pelayanan keperawatan di Rumah Sakit. 


\section{METODE}

Metode dalam kajian literature ini menggunakan perangkat PICO (Population, Intervention, Comparison dan Outcome). Pertanyaan penelitiannya adalah: "Apakah implementasi Integrated Clinical Pathway memiliki pengaruh terhadap mutu pelayanan keperawatan di Rumah Sakit?"

Perangkat pertanyaan:

Populasi : pasien di rumah sakit

Intervensi : integrated clinical pathway

Comparison : standar asuhan keperawatan

Outcome : peningkatan mutu pelayanan keperawatan di Rumah Sakit.

Pertanyaan penelitian: "Apakah implementasi Integrated Clinical Pathway memiliki pengaruh terhadap mutu pelayanan keperawatan di Rumah Sakit?" Adapun sumber yang dapat diakses untuk penelitian adalah EBSCO, ProQuest, Scopus, JKI dan artikel lain dengan kata kunci, clinical pathway, manajemen keperawatan, mutu pelayanan dan sistem informasi. Kriteria inklusi pada penelitian ini adalah: pasien di RS, perawat dan sumber data 5 tahun terahir.

\section{PEMBAHASAN}

\section{Kajian Literatur}

Clinical pathway adalah alur yang menunjukkan secara detail tahap-tahap penting dari pelayanan kesehatan termasuk hasil yang diharapkan. Secara sederhana dapat dibilang bahwa clinical pathway adalah sebuah alur yang menggambarkan proses mulai saat penerimaan pasien hingga pemulangan pasien. Clinical pathway memiliki banyak nama lain seperti: Critical care pathway, Integrated care pathway, Coordinated care pathway, Caremaps (alur perawatan, alur kritis, alur perawatan terintegrasi atau peta perawatan), adalah salah satu perangkat utama yang digunakan untuk mengelola kualitas pelayanan kesehatan mengenai standardisasi proses perawatan (Yasman, 2012).

Sitorus mengutip pernyataan Muller bahwa penerapan clinical pathways merupakan sebuah pendekatan yang dapat digunakan dalam rasionalisasi biaya tanpa mengurangi mutu. Care pathways merupakan "the heart of quality and patient safety". Care pathways menjadi sangat penting sebagai petunjuk tim multidisiplin termasuk klinikan, para manajer dan pasien sampai pada tingkatan pelaksanaan sehari- hari (Olsson, Hansson et al. 2009)

Tujuan utama implementasi ICP menurut Depkes RI (2010) adalah untuk: Memilih "best practice" pada saat pola praktek diketahui berbeda secara bermakna, Menetapkan standar yang diharapkan mengenai lama perawatan dan penggunaan pemeriksaan klinik serta prosedur klinik lainnya, Menilai hubungan antara berbagai tahap dan kondisi yang berbeda dalam suatu proses serta menyusun strategi untuk mengkoordinasikan agar dapat menghasilkan pelayanan yang lebih cepat dengan tahapan yang lebih sedikit, Memberikan peran kepada seluruh staf yang terlibat dalam pelayanan serta peran mereka dalam proses tersebut, Menyediakan kerangka kerja untuk mengumpulkan dan menganalisa data proses pelayanan sehingga operator dapat mengetahui seberapa sering dan mengapa seorang pasien tidak mendapatkan pelayanan sesuai standar. Mengurangi beban dokumentasi klinik, Meningkatkan kepuasan pasien melalui peningkatan edukasi 
kepada pasien, misalnya dengan menyediakan informasi yang lebih tepat tentang rencana pelayanan.

ICPAT merupakan salah satu instrument yang sudah divalidasi dan dapat digunakan untuk melakukan evaluasi dari isi dan mutu ICP, yang terdiri dari 6 dimensi (Whittle, 2009) yaitu: Dimensi 1: Bagian ini memastikan apakah formulir yang dinilai adalah Clinical Pathway (CP). Hal ini disebabkan karena ada banyak kesimpangsiuran pengertian dan definisi CP. Maka langkah pertama yang perlu dilakukan adalah untuk menilai apakah suatu guideline yang akan kita nilai adalah $\mathrm{CP}$ atau bukan. Dimensi

2: Menilai proses dokumentasi ICP. CP adalah formulir yang digunakan secara aktual untuk mendokumentasikan pelayanan / terapi yang diberikan kepada masing-masing pasien. Dokumentasi ini termasuk untuk mencatat kepatuhan maupun ketidakpatuhan (variasi). Dimensi 3: Menilai proses pengembangan CP sama pentingnya dengan CP yang dihasilkan, karena CP merupakan sebuah alat yang akan digunakan untuk mengevaluasi pelayanan / terapi yang telah diberikan dan untuk memperbaiki pelayanan tersebut sehingga akan melibatkan proses perubahan dalam praktek sehari-hari. Dimensi 4: Menilai proses implementasi ICP. Definisi dari penerapan (implementasi) $\mathrm{CP}$ adalah saat proses pengembangan $\mathrm{CP}$ (termasuk uji coba) telah selesai dilakukan dan tim yang mengembangkan telah siap untuk menerapkannya dalam praktek sehari-hari. Dalam bagian ini pertanyaan-pertanyaan yang dibuat adalah untuk memastikan efektifitas penerapan dan penggunaan $\mathrm{CP}$. Dimensi 5: Menilai proses pemeliharaan ICP. Salah satu faktor sukses terpenting dalam penggunaan $\mathrm{CP}$ adalah kegiatan untuk menjaga $\mathrm{CP}$ yang mensyaratkan $\mathrm{CP}$ berfungsi sebagai alat dinamis yang dapat merespon masukan dari staf, pasien, respon klinis, referensi terbaru sehingga isi dan desain dari CP perlu direview terus menerus. Dimensi 6: Menilai peran organisasi (RS). Peran organisasi merupakan salah satu hal penting yang akan mendukung proses pelaksanaan ICP.

\section{Kelebihan Penggunaan ICP}

Banyak rumah sakit mulai menerapkan ICP dalam pemberian pelayanan kesehatan kepada pasien, karena penggunaan ICP memiliki kelebihan antara lain sebagai berikut: Pertama ICP adalah format pendokumentasian dari multidisiplin ilmu. Format ini dapat memberikan efisiensi dalam pencatatan, menghindari duplikasi penulisan, sehingga menghindari kemungkinan kesalahan komunikasi dalam tim kesehatan saat merawat pasien. Kedua, meningkatkan pengetahuan dan kompetensi dari tim multidisplin saat berkomunikasi dengan pasien. Ketiga, memiliki standarisasi outcome sesuai lamanya hari rawat, sehingga akan tercapai effective cost dalam perawatan pasien. Keempat, dapat meningkatkan kepuasan pasien karena pelaksanaan discharge planning lebih jelas sehingga mampu meningkatkan mutu pelayanan (Yasman, 2012).

\section{Kekurangan Penggunaan ICP}

Selain mempunyai kelebihan dalam penggunaan ICP, perlu dicermati juga kekurangan yang ditemui dalam penerapan format ICP ini, antara lain sebagai berikut: Kurangnya pengetahuan terhadap pentingnya clinical pathway karena sosialisasi dan pelatihan yang diberikan belum optimal.

a. Tidak terlihat proses keperawatan secara jelas karena harus menyesuaikan dengan tahap perencanan medis, pengobatan, dan pemeriksaan penunjang lainnya. 
b. Dokumentasi ICP ini membutuhkan waktu yang relatif lama dalam pembentukan dan pengembangannya karena terbatasnya sumber daya.

c. Format dokumentasi hanya digunakan untuk per masalah spesifik tidak untuk keseluruhan penyakit sehingga tidak efisien dari segi alat.

d. Masih rendahnya kepatuhan dalam pendokumentasian clinical pathway karena dianggap sebagai beban kerja tambahan bagi para staf (Astuti, Dewi et al. 2017).

Proses Keperawatan digunakan sebagai kerangka kerja dalam pembuatan clinical pathway. Dalam membuat clinical pathway, proses keperawatan digunakan sebagai kerangka kerja. Proses keperawatan memberikan template untuk keberhasilan gabungan dari orientasi pada pasien, kesepakatan dalam manajemen pengobatan yang dihasilkan untuk memperbaiki pelayanan dengan meningkatkan patient safety dan biaya yang efektif sehingga clinical pathway dapat meningkatkan mutu pelayanan keperawatan dan kepuasan pasien.

Mutu pelayanan kesehatan adalah suatu bentuk intervensi terintegrasi kepada pasien secara aman dan sesuai standar profesi dengan memanfaatkan sumber daya yang terlatih sehingga kebutuhan pasien dapat terpenuhi dan mencapai derajat kesehatan yang optimal. Mutu pelayanan keperawatan profesionalitas berlandaskan pada 5 dimensi kualitas pelayanan yaitu: reability, tangibles, assurance, responsiveness, dan empathy. Pengaruh faktor mutu pelayanan, antara lain: aspek kompetensi teknis, aspek pelayanan, efektifitas, efisiensi, hubungan antar manusia, keamanan, kenyamanan dan kesinambungan terhadap kepuasan pasien (Muninjaya, 2011).

Hal ini juga didukung dari artikel yang membahas mengenai penerapan clinical pathway dalam meningkatkan kepedulian pada sesama, didapatkan bahwa clinical pathway memiliki pengaruh yang positif terhadap kualitas perawatan yang diberikan pada pasien, dimana dapat membantu meningkatkan mutu pelayanan di rumah sakit (Buchert and Butler 2016). Terdapat perbedaan signifikan terhadap biaya perawatan stroke iskemik akut setelah penerapan $\mathrm{CP}$ pada pasien, dimana mampu menurunkan biaya perawatan secara signifikan sehingga dapat meningkatkan mutu pelayanan kesehatan (Iroth, Ahmad et al. 2017).

Penerapan clinical pathway menurut standar penilaian ICPAT dan pada bagian konten dan mutu termasuk dalam kriteria moderate. Peran organisasi rumah sakit pada aspek konten masuk dalam kriteria baik, sedangkan aspek mutu termasuk dalam kriteria moderate (Astuti, Dewi et al. 2017). Pada penelitian penerapan clinical pathway yang dilakukan oleh staf keperawatan pada pasien kanker, memberi pengalaman memuaskan bagi staf karena dapat mengasah pengetahuan dan kemampuan professional saat memberikan asuhan keperawatan sehingga dapat meningkatkan kualitas perawatan pasien dan mutu pelayanan meningkat (Zhou, Ruan et al. 2017).

Menurut salah satu penelitian menyatakan bahwa clinical pathway telah diterapkan di RSUP Prof Dr. R. D. Kandou dan memberi manfaat penting bagi mutu pelayanan kesehatan menjadi lebih baik, adanya kepastian rencana untuk tata laksana pasien, mengurangi length of stay pasien, dan mengontrol biaya. Implementasi clinical pathway sangat erat berhubungan dan berkaitan dengan clinical governance dalam rangka 
menjaga dan meningkatkan mutu pelayanan dengan biaya yang dapat di estimasi dan terjangkau (Cicilia, Erwin et al. 2017).

Dari penelitian didapatkan hasil implementasi clinical pathway dapat menurunkan average length of stay, namun belum mampu membuktikan adanya perbedaan pada outcomes pasien anak dengan DF-DHF di RSUD Kota Yogyakarta (Fadilah and Budi 2018). Berdasarkan penelitian yang dilakukan di Rumah Sakit didapatkan hasil mutu pelayanan keperawatan juga membaik hanya di kelompok intervensi $(62,9 \%$ vs $97,1 \%)$ setelah penerapan clinical pathway. Penerapan clinical pathway mempengaruhi kepuasan pasien dan mutu pelayanan keperawatan memberikan pengaruh terhadap kepuasan pasien (Widjaja, Wijayanti, \& Tjirta, 2019).

\section{SIMPULAN}

Sesuai dengan Permenkes RI No. 69 tahun 2014 tentang Kewajiban Rumah Sakit dan Kewajiban Pasien pasal 24 ayat 1 menyatakan bahwa pasien memiliki hak memperoleh layanan kesehatan yang bermutu sesuai dengan standar profesi dan standar prosedur operasional. Salah satu strategi rumah sakit untuk meningkatkan mutu pelayanan adalah penerapan clinical pathway atau integrated clinical pathway (ICP).

Clinical pathway adalah rencana kolaboratif asuhan pasien yang dilakukan secara multidisiplin, yaitu kerjasama antar dokter, perawat, staf klinis, dan staf penunjang. Clinical Pathway terintegrasi merupakan bagian penting dokumen yang melibatkan Profesional Pemberi Asuhan sebagai intradisiplin dan interdisiplin dengan kolaborasi interprofesional dalam pemberian asuhan pada pasien di Rumah Sakit (KARS, 2017). Implementasi clinical pathway dapat menjadi sarana dalam terwujudnya tujuan akreditasi rumah sakit yakni dalam meningkatkan mutu pelayanan rumah sakit, meningkatkan keselamatan pasien rumah sakit dan meningkatkan perlindungan bagi pasien, masyarakat serta sumber daya rumah sakit (Kemenkes, 2012).

Clinical Pathway berbentuk dokumentasi keperawatan professional terpadu, yang mampu memastikan bahwa pasien menerima perawatan terbaik setiap saat dan dapat memberikan peningkatan mutu pelayanan bagi organisasi. ICP merupakan format dokumentasi multidisplin secara umum dapat diterapkan di Indonesia atas pertimbangan kebutuhan untuk memperbaiki kualitas dokumentasi, kebutuhan untuk mengurangi waktu perawat mencatat, kebutuhan menghemat biaya, mengurangi duplikasi, mengurangi salah komunikasi dan penekanan pada hasil yang ingin dicapai pasien.

Kekurangan yang mungkin ditemui dalam format dokumentasi multidisiplin adalah tidak terlihatnya proses keperawatan secara jelas, masih rendahnya kepatuhan dalam pendokumentasian clinical pathway karena dianggap sebagai beban kerja tambahan bagi para staf dan kurangnya pengetahuan terhadap pentingnya clinical pathway karena sosialisasi dan pelatihan yang diberikan belum optimal.

Clinical pathway adalah rencana kolaboratif dalam pemberian asuhan pada pasien yang melibatkan dokter, perawat, staf klinis dan staf penunjang. Alat dokumentasi primer yang menjadi bagian dari keseluruhan proses dokumentasi asuhan dan dalam mengoperasionalkannya terintegrasi dalam sistem informasi manajemen. Clinical 
pathway dapat digunakan untuk memberikan pelayanan keperawatan professional dengan menghemat waktu dan tenaga. Dari berbagai penelitian, didapatkan hasil bahwa implementasi clinical pathway yang optimal dengan evaluasi berkelanjutan memiliki banyak manfaat dan terbukti mampu meningkatkan kepuasan pasien sehingga mutu pelayanan keperawatan dapat meningkat.

Hasil penelitian ini diharapkan dapat dijadikan bahan masukan pengembangan dan menambah kepustakaan bagi institusi pendidikan dalam menerapkan intervensi clinical pathway guna meningkatkan mutu asuhan keperawatan. Dapat memberikan masukan bagi Rumah Sakit untuk aktif menerapkan intervensi clinical pathway secara optimal guna meningkatkan mutu pelayanan keperawatan. Diperlukannya berbagai sosialisasi dan pelatihan pengisian clinical pathway bagi staf organisasi dan kesadaran tim kesehatan untuk meningkatkan pengetahuan juga keterampilan klinisnya melalui penggunaan clinical pathway.

\section{REFERENSI}

Astuti, Y., et al. (2017). "Evaluasi Implementasi Clinical Pathway Sectio Caesarea Di RSUD Panembahan Senopati Bantul." Jurnal Medicoeticolegal dan Manajemen Rumah Sakit 6(2): 97-111..

Buchert, A. R. M. D. and G. A. M. S. N. R.N. Butler (2016). "Clinical Pathways." Pediatric Clinics of North America 63(2): 317-328.

Cicilia, P., et al. (2017). "Analisis pelaksanaan clinical pathway di RSUP Prof. Dr. R. D. Kandou Manado." Jurnal Biomedik 9(1).

Depkes RI. (2010). Clinical Pathway. Jakarta: Ditjen Bina Pelayanan Medik.

Fadilah, N. F. N. and S. C. Budi (2018). "Efektifitas Implementasi Clinical Pathway Terhadap Average Length Of Stay dan Outcomes Pasien DF- DHF Anak di RSUD Kota Yogyakarta." JKesVo Jurnal Kesehatan Vokasional 2(2): 175.

Iroth, J. S., et al. (2017). "Dampak Penerapan Clinical Pathway Terhadap Biaya Perawatan Pasien Stroke Iskemik Akut Di Rs Bethesda Yogyakarta." berk.ilm.kedokt.duta.wacana. Berkala Ilmiah Kedokteran Duta Wacana 2(1): 267.

Muninjaya, A. (2011). Manajemen Mutu Pelayanan Kesehatan. Jakarta: EGC. Olsson, L. E., et al. (2009). "A cost- effectiveness study of a patient- centred integrated care pathway." Journal of Advanced Nursing 65(8): 1626-1635.

Sitorus (2011) Penerapan Clinical Pathways Terbukti Mampu Menurunkan Biaya Pengobatan di RS, www.ugm.ac.id/.../3142-penerapan- clinical-pathway, diakses 11 Oktober 2019.

Whittle, C. (2009). ICPAT: Integrated care pathway appraisal tools. International Journal of Care Pathway, 13, pp. 75-77.

Widjaja, L., Wijayanti, C., \& Tjirta, E. (2019). Pengaruh Clinical Pathway Terhadap Mutu Pelayanan Keperawatan Dan Kepuasan Pasien. Jurnal Ilmiah Ilmu Keperawatan Indonesia, 09.

Yasman, Y. (2012). Penerapan Integrated Care Pathways (ICP) Sebagai Bagian Sistem Informasi Manajemen Keperawatan Di Rumah Sakit. Depok: Universitas Indonesia.

Zhou, J., et al. (2017). "Application of clinical pathway management in the training and practice of nursing staff for cancer patients." $\underline{\text { Biomed. Res. Biomedical }}$ Research (India) 28(17): 7574-7577. 